Canadian

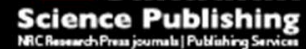

Canadian Journal of Microbiology Revue canadienne de de microbiologie

\title{
Feces of feedlot cattle contain a diversity of bacteriophages that lyse non-0157 Shiga toxin-producing Escherichia coli
}

\begin{tabular}{|r|l|}
\hline Journal: & Canadian Journal of Microbiology \\
\hline Manuscript ID: & cjm-2015-0163.R1 \\
\hline Manuscript Type: & Article \\
\hline Complete List of Authors: & $\begin{array}{l}\text { Wang, Jiaying; South China Agricultural University, College of Veterinary } \\
\text { Medicine; Alberta Agriculture and Rural Development, } \\
\text { Niu, Yan; Alberta Agriculture and Rural Development, } \\
\text { Chen, Jinding; South China Agricultural University, College of Veterinary } \\
\text { Medicine } \\
\text { Anany, Hany; Canadian Research Institute for Food Safety, Department of } \\
\text { Food Science; ain shams university faculty of science, microbiology } \\
\text { department } \\
\text { Ackermann, Hans; Université Laval, Département de microbiologie, Faculté } \\
\text { de médecine } \\
\text { Johnson, Roger; Public Health Agency of Canada, Laboratory for Foodborne } \\
\text { Zoonoses } \\
\text { Ateba, Collins Njie; North West Univ, Biological Sciences } \\
\text { Stanford, Kim; Alberta Agriculture and Rural Development } \\
\text { McAllister, Tim A.; Agriculture and Agri-Food Canada }\end{array}$ \\
\hline Keyword: & \begin{tabular}{l} 
Bacteriophages, biocontrol, Escherichia coli, non-O157, cattle \\
\hline
\end{tabular} \\
\hline
\end{tabular}


Running headline: bacteriophages against non-O157 STEC

2

Feces of feedlot cattle contain a diversity of bacteriophages that lyse non-O157 Shiga

toxin-producing Escherichia coli

5

Jiaying Wang ${ }^{1,3}$, Yan D. Niu ${ }^{2 *}$, Jinding Chen ${ }^{1}$, Hany Anany ${ }^{4,5}$, Hans-W Ackermann ${ }^{6}$,

7 Roger P. Johnson ${ }^{7}$, Collins N. Ateba ${ }^{8}$, Kim Stanford $^{2}$, Tim A. McAllister $^{3}$

Guangdong, P.R. China 510642;

17 Canada G1K 7P4;

${ }^{2}$ Alberta Agriculture and Rural Development, Lethbridge, AB, Canada T1J 4V6;

${ }^{3}$ Agriculture and Agri-Food Canada, Lethbridge, AB, Canada T1J 4B1;

${ }^{4}$ Department of Food Science, Canadian Research Institute for Food Safety, Guelph, ON,

\section{Canada N1G 2W1;}

${ }^{5}$ Department of Microbiology, Faculty of Science, Ain Shams University, Cairo, Egypt;

${ }^{6}$ Département de microbiologie, Faculté de médecine, Université Laval, Québec, QC,

19 Canada N1G 3W4;

${ }^{8}$ Department of Biological Sciences, Faculty of Agriculture Science and Technology,

21 North West University-Mafikeng Campus, North West, Mmabatho, South Africa 2735 
$23 \quad{ }^{*}$ Corresponding author: Y.D. Niu, Alberta Agriculture and Rural Development, \#100-

24 5401-1st Ave. South, Lethbridge, Alberta T1J 4V6, Canada. Tel: +1-403-381-5351 Fax: +1-403-

25 382-4526 E-mail: dongyan.niu@gov.ab.ca

26

27 Email addresses:

28 JW: Jiaying.wang@agr.gc.ca

29 YDN: dongyan.niu@gov.ab.ca

$30 \quad$ JC: jdchen@scau.edu.cn

$31 \quad$ HA: hanany@alumni.uoguelph.ca

32 HWA: ackermann4@gmail.com

33 RPJ: Roger.Johnson@phac-aspc.gc.ca

34 CAN: atebacollins1@hotmail.com

$35 \quad$ KS: kim.stanford@gov.ab.ca

36 TAM: tim.mcallister@,AGR.GC.CA 


\section{Abstract}

This study aimed to isolate and characterize bacteriophages that lyse non-O157 Shiga

40 toxin-producing Escherichia coli (STEC) from cattle feces. Of 37 non-O157 STEC-infecting

41 phages isolated, O26- (AXO26A, AYO26A, AYO26B), O103-(AXO103A, AYO103A), O111-

42 (AXO111A, AYO111A), O121-(AXO121A, AXO121B) and O145- (AYO145A, AYO145B)

43 targeting phages were further characterized. Transmission electron microscopy showed the 11

44 isolates belonged to 3 families and 6 genera: the families Myoviridae (types rV5, T4, ViI, O1),

45 Siphoviridae (type T5) and Podoviridae (type T7). Genome size of the phages as determined by

46 pulsed-field gel electrophoresis ranged from 38 to $177 \mathrm{~kb}$. Excluding phages AXO26A,

47 AYO103A, AYO145A and AYO145B, all other phages were capable of lysing more than one

48 clinically important strain from serogroups of O26, O91, O103, O111, O113, O121 and O128,

49 but none exhibited infectivity across all serogroups. Moreover, phages AYO26A, AXO121A and

50 AXO121B were also able to lyse 4 common phage types of STEC O157:H7. Our findings show

51 that a diversity of non-O157 STEC-infecting phages are harbored in bovine feces. Phages

52 AYO26A, AYO26B, AXO103A, AXO111A, AYO111A, AXO121A and AXO121B exhibited a

53 broad host range against a number of serogroups of STEC and have potential for the biocontrol

54 of STEC in the environment.

55

56 Keywords: Bacteriophages, biocontrol, Escherichia coli, non-O157, cattle 


\section{Introduction}

Shiga toxin-producing Escherichia coli (STEC), in particular serogroups O26, O45,

60 O103, O111, O121 and O145 are increasingly being recognized as important foodborne

61 pathogens that cause outbreaks and sporadic cases of illnesses in humans worldwide (Johnson et

62 al. 2006; Mathusa et al. 2010; Luna-Gierke et al. 2014; Smith et al. 2014). The severity of

63 illnesses caused by non-O157 STEC may equal or even exceed that associated with STEC

64 O157:H7, with clinical manifestations including diarrhea, hemorrhagic colitis, and hemolytic

65 uremic syndrome (Johnson et al. 2006; Hermos et al. 2011). Cattle are recognized as primary

66 reservoirs of non-O157 STEC (Hussein and Bollinger 2005; Smith et al. 2014) and contaminated

67 foods of bovine origin (Ethelberg et al. 2009; Mathusa et al. 2010; Robbins et al. 2014) or

68 vegetable products contaminated with bovine feces (Hussein and Bollinger 2005; Smith et al.

69 2014) can be sources of infection for humans. The "top 6" non-O157 STEC (O26, O45, O103,

$70 \mathrm{O} 111, \mathrm{O} 121$ and $\mathrm{O} 145$ ) have been declared as adulterants in raw beef products in the United

71 States (USDA 2012). Having different evolutionary histories from O157 serotype, non-O157

$72 \mathrm{STEC}$ are a heterogeneous group of $E$. coli with limited information available about their

73 virulence, fitness, and stress responses (Wang et al. 2013). This lack of knowledge and great

74 heterogeneity of strains increases the complexity of developing strategies to reduce the risk of

75 food and water becoming contaminated with these pathogens.

Bacteriophages (phages) are bacterial viruses that are abundant in the environment

78 (Weinbauer, 2004).The capability of phages to infect specific bacterial pathogens without

79 impacting commensal bacteria makes phage therapy a promising alternative to antimicrobials 
80 (Kutateladze and Adamia 2010), especially with the ongoing challenges that antimicrobial

81 resistance is presenting to the medical profession (Poole 2003; Mahony et al. 2011). Researchers

82 have demonstrated that phages are potentially effective in mitigating STEC O157:H7 in

83 ruminants (Sheng et al. 2006; Callaway et al. 2008; Raya et al. 2011) and decontaminating food

84 products such as beef, broccoli, tomato, lettuce and spinach (Abuladze et al. 2008; Carter et al.

85 2012; Hong et al. 2014). Moreover, STEC O157:H7-infecting phages have been isolated from

86 cattle feces (Callaway et al. 2008; Niu et al. 2009a; Hallewell et al. 2014) and phage ecology

87 plays an important role in the fecal shedding of STEC O157:H7 in cattle and their environment

88 (Niu et al. 2009a; Hallewell et al. 2014). To date, however, there are few reports on lytic

89 properties of phages targeting non-O157 STEC, although phages with limited activity against

90 non-O157 STEC serogroups have been isolated from ruminant feces (Viscardi et al. 2008; Dini

91 and De Urraza 2010). Given these reports and the similarity of biological and epidemiological

92 characteristics between STEC O157:H7 and non-O157 STEC serogroups (Smith et al., 2014), we

93 hypothesize that bovine feces would also be a natural source of phages with activity against non-

94 O157 STEC. Consequently, the aims of the present study were to isolate and characterize

95 endemic phages with activity against the "top 6" non-O157 STEC in cattle.

\section{Materials and methods}

\section{Bacterial strains and growth conditions}

All bacterial strains used in this study (Table 1) were obtained from Public Health

100 Agency of Canada, Laboratory for Foodborne Zoonoses, Guelph, ON. These strains comprised 101 four strains of human or bovine origin of each of the "top 6" non-O157 STEC serogroups O26, $102 \mathrm{O} 45, \mathrm{O} 103, \mathrm{O} 111, \mathrm{O} 121$, and $\mathrm{O} 145$, four strains of three other non-O157 serogroups implicated 
103 in serious illness (O91, O113 and O128) and five strains of STEC O157:H7 representing the four

104 most common phage types isolated from cattle and humans. Strains of some non-O157 STEC

105 serogroups included serotypes with different $\mathrm{H}$ antigens (O111, O145, O113, O128, and O91).

106 For isolation, purification, propagation, and titration of phages, STEC O26:H11 EC19970119,

107 STEC O45:H2 EC19940040, STEC O103:H2 EC20010670, STEC O111:NM EC20030053,

108 STEC O121:H19 EC20040083 and STEC O145:NM EC20020231 were singly used as hosts. All

109 non-O157 STEC strains $(\mathrm{n}=36)$ and STEC O157:H7 strains $(\mathrm{n}=5)$ were used to evaluate host

110 range and lytic capability of isolated phages. All bacterial strains were grown in tryptic soy broth

111 (TSB, EMD Millipore, ON, Canada), and/or tryptic soy agar (TSA, Dalynn, Calgary, AB,

112 Canada) at $37^{\circ} \mathrm{C}$ for $18 \mathrm{~h}$.

113

\section{Samples collection, phages isolation and propagation}

Beef cattle fecal samples were obtained every two weeks from May 2013 to August 2013

116 from livestock transport trailers (A-E, 47 cattle per trailer) in Alberta, Canada (Fig. 1 and

117 Table 2). Approx. five 100-g fecal samples were collected from fresh fecal pats in each trailer

118 compartment and pooled into a sterile whirl-Pak bag (Nasco, Salida, CA, USA) and transported

119 to the laboratory within $12 \mathrm{~h}$ in an electric cooler (Model 5645, Coleman, Golden, CO, USA). To

120 isolate phages from fecal samples, whirl-Pak bags containing feces were hand mixed to ensure

121 homogeneity and then $20-\mathrm{g}$ was transferred into $60 \mathrm{ml}$ of sterile Lambda diluent $\left(10 \mathrm{mmol} \cdot \mathrm{l}^{-1}\right.$

122 Tris $\mathrm{Cl}, \mathrm{pH} 7.5,8 \mathrm{mmol} \cdot \mathrm{l}^{-1} \mathrm{MgSO}_{4}$ ) and processed in a laboratory mixer (Stomacher 400

123 Circulator, Seward Medical, London, UK) for $1 \mathrm{~min}$ at $230 \mathrm{rev} \mathrm{min}^{-1}$. The samples were then

124 allowed to stand for 30-60 min at room temperature to sediment large particulates and allow

125 migration of phage particles into the buffer. A subsample of liquid $(20 \mathrm{ml})$ was extracted from 
126 the top layer, centrifuged at $11,000 \mathrm{~g}$ for $10 \mathrm{~min}$, and filtered through a sterile 50 -ml disposable

127 vacuum filtration unit $(0.2-\mu \mathrm{m}$; Millipore, Billerica, MA, USA). The filtrate $(1 \mathrm{ml})$ was added to 128 a 5-ml early log phase $(\mathrm{OD} 600=0.2-0.3)$ culture of each single serotypes of non-O157 STEC in

$129 \mathrm{TSB}$ with $10 \mathrm{mmol} \cdot 1^{-1} \mathrm{MgSO}_{4}$ and further incubated at $37^{\circ} \mathrm{C}$ in a rotary shaker $\left(150 \mathrm{rev} \mathrm{min}^{-1}\right)$

130 (New Brunswick Scientific, Co., INC. Edison, NJ, USA) for 20 h. Individual phages were

131 obtained by three cycles of plaque purification using the soft agar overlay technique (Sambrook

132 and Russell 2001) and stock filtrates were prepared using the same non-O157 STEC strain of

133 each serogroup as a host as described previously (Niu et al. 2012). Titers of phages in the stock

134 filtrates were then determined by the soft agar overlay technique (Sambrook and Russell 2001).

\section{Electron microscopy}

For electron microscopy, phages were sedimented for $60 \mathrm{~min}$ at $18,000 \mathrm{~g}$ using a

138 Microfuge ${ }^{\circledR}$ R centrifuge (Beckman Coulter Inc., Mississauga, ON, Canada). Samples were 139 washed in buffer $\left(10 \mathrm{mmol} \cdot \mathrm{l}^{-1}\right.$ Tris $\mathrm{Cl}, \mathrm{pH} 7.5,10 \mathrm{mmol} \cdot \mathrm{l}^{-1} \mathrm{MgSO}_{4}, 6.7 \mathrm{mmol} \cdot \mathrm{l}^{-1} \mathrm{CaCl}_{2}, 0.5 \%$

140 (w/v) gelatin) and centrifuged for $60 \mathrm{~min}$ at 18,000 $\mathrm{g}$. Purified phages were deposited on carbon141 coated Formvar films on copper grids, stained with $2 \%$ Uranyl acetate $(\mathrm{pH} 4-4.5)$, and examined 142 in a FEI Tecnai electron microscope (Tecnai G2 F20 model FEI, USA) at $200 \mathrm{kV}$.

\section{Phage microplate virulence assay}

Host range and lytic capability of the phages were assessed using a microplate phage

146 virulence assay (Niu et al. 2009b). Briefly, high-titre phage stocks $\left(10^{8}-10^{10} \mathrm{PFU} \mathrm{ml}^{-1}\right)$ were

147 serially diluted in $96-$-well microplates and incubated for $5 \mathrm{~h}$ at $37^{\circ} \mathrm{C}$ with overnight cultures of

148 bacterial strains to estimate multiplicity of infection (MOI). After incubation, wells were 
149 examined visually for turbidity and the highest dilution that resulted in complete lysis of bacteria

150 was recorded. The MOI for each phage-host assay was calculated by dividing the initial number

151 of phages in the highest-dilution causing complete lysis by the initial number of bacteria added,

152 as determined by serially diluted plate counts of bacterial culture. Strains were then defined as

153 sensitive $(0.000001 \leqslant \mathrm{MOI}<100)$ or resistant $(\mathrm{MOI} \geqslant 100$ as complete lysis did not occur $)$ to

154 the phages tested. Sensitivity to phage was further categorized as follows: extremely susceptible:

$155(0.000001 \leq \mathrm{MOI}<0.01)$; highly susceptible: $(0.01 \leq \mathrm{MOI}<1)$; moderately susceptible: $(1 \leq$

$156 \mathrm{MOI}<10)$; and minimally susceptible: $(10 \leq \mathrm{MOI}<100)$.

Genome size estimation and restriction fragment length polymorphism (RFLP)

Bacterial nucleotides were removed from crude phage lysates $\left(10^{8}-10^{10} \mathrm{PFU} \mathrm{ml} \mathrm{m}^{-1}\right) \mathrm{using}$

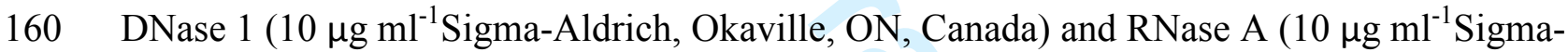

161 Aldrich), and the phage lysates were concentrated by use of polyethylene glycol 8000 (Sambrook

162 and Russell 2001). Concentrated phage lysates were subjected to pulsed field gel electrophoresis

163 (PFGE) for determination of genome size (Lingohr et al. 2009; Niu et al. 2012) using a CHEF

164 DR II electrophoresis unit (Bio-Rad Laboratories, Mississauga, ON, Canada). For restriction

165 enzyme analysis, phage DNA embedded in 1\% SeaKem Gold agarose (Lonza, Rockland, ME,

166 USA) was digested respectively, with Acc65I, BamHI, EcoRI, EcoRV, KpnI, HaeII, HindIII,

167 SacI, SalI, PstI, XbaI and XhoI (New England Biolabs, Pickering, ON, Canada) for $16 \mathrm{~h}$ at $37^{\circ} \mathrm{C}$.

168 The plugs were then subjected to PFGE for $16-18 \mathrm{~h}$ using a pulse time of $1.0-15.0 \mathrm{~s}, 6 \mathrm{~V} \cdot \mathrm{cm}^{-1}$

169 alongside with Low Range PFG marker (New England Biolabs). All PFGE digital images were

170 then analyzed using BioNumerics 5.1 software (Applied Maths, Inc., Austin, TX). Restriction

171 digestion banding patterns were analyzed using Dice similarity coefficients, unweighted pair 
172 group methods arithmetic average algorithm with a $1 \%$ position tolerance, and $0.5 \%$

173 optimization.

\section{Results}

\section{Phage isolation}

A total of 37 phages infecting serogroups O26 $(n=10)$, O103 $(n=2)$, O111 $(n=2)$,

$178 \mathrm{O} 121(\mathrm{n}=12)$ and $\mathrm{O} 145(\mathrm{n}=11)$ were isolated, but no phages with activity against $\mathrm{O} 45$ were

179 isolated (Data not shown). For each serogroup, 2-3 phage isolates were selected for further

180 characterization based on having a high titer against their corresponding host upon initial

181 isolation (Tables 2 and 3). Each phage was designated as vB (bacterial virus), followed by Eco

182 (Escherichia coli), M or S or P (Myoviridae or Siphoviridae or Podoviridae), A (Alberta), X or

183 Y (Slaughter plants), specific serotypes of host for isolation with the suffix A or B (first or

184 second phage isolates being characterized). For example, a phage isolated from serotype 26 is

185 designated vB_EcoS_AXO26A, with AXO26A as the short form. Among the 11 phages, phages

186 vB_EcoS_AXO26A, vB_EcoS_AXO103A and vB_EcoM_AXO121A were simultaneously

187 isolated from fecal sample A of trailer A. vB_EcoM_AYO26A, vB_EcoP_AYO103A,

188 vB_EcoM_AYO111A and vB_EcoM_AYO145A were concurrently isolated from fecal sample

189 C of trailer C, and vB_EcoM_AYO26B were isolated along with vB_EcoM_AYO145B from

190 fecal sample D of trailer D.

191

192

193

Phage Morphology

Overall, 11 phages displayed 6 distinct morphotypes upon examination using

194 transmission electron microscopy (TEM; Table 3, Fig. 2). Structurally, excluding phages 
195 AXO26A, AXO103A and AYO103A, all other phages had a long, contractile tail and were 196 therefore assigned to the Myoviridae family. Phage AXO121A had an icosahedral head with 197 diameter of $93 \mathrm{~nm}$ between opposite apices and an extended tail of $122 \times 17 \mathrm{~nm}$. Five to six thin 198 tail fibers of $61 \mathrm{~nm}$ in length were occasionally seen. The morphology of AXO121A closely 199 resembles that reported for phage $\mathrm{rV5}$, in which the head measured $91 \mathrm{~nm}$ in diameter and the 200 contractile tail was $121 \times 17 \mathrm{~nm}$ with $70 \mathrm{~nm}$ tail fibers (Kropinski et al. 2013). Phages AYO26A 201 and vB_EocM_AXO121B had a large elongated head with diameter of 115-117 nm. Striated 202 contractile tails measured 109-118 × 21-24 nm with a collar, base plate, short spikes and long 203 fibers $(\sim 133 \mathrm{~nm})$. As a result, they were characterized as T4-like phages. Phages AYO26B and 204 vB_EcoM_AXO111A possessed an icosahedral head of $95 \mathrm{~nm}$ in diameter and a contractile tail 205 of 100-102 $\times 16-20 \mathrm{~nm}$ with terminal spikes, which corresponds to the morphology of 206 Salmonella Typhi phage ViI and E. coli O157:H7-specific phage vB_EcoM_CBA120

207 (Ackermann et al. 1970; Pickard et al. 2010; Kutter et al. 2011). As such, they were classified as 208 ViI-like phages. Phages AYO111A, AYO145A and AYO145B shared similar morphology, with 209 the icosahedral heads of the former two being slightly smaller than the latter, resembling those of 210 phage Felix O1, in which the head measured $73 \mathrm{~nm}$ in diameter and the non-contractile tail was

$211113 \times 17 \mathrm{~nm}$ long (Ackermann 2007). Interestingly, ViI-like phages AYO26B and AXO111A

212 shared the same head shape and diameter and tail length as the O1-like phage AYO111A,

213 although different tail fiber structures were observed with the former two showing an intricate

214 array of tail fibers and the latter displaying folded, long-tail fibers (Fig. 2C and 2G). In contrast,

215 phages AXO26A and AXO103A had an icosahedral head 82-85 $\mathrm{nm}$ in diameter, but long

$216(178-196 \times 10 \mathrm{~nm})$ rigid, non-contractile tails that ended in a conical structure with terminal

217 fibers $(23 \times 4 \mathrm{~nm})$. This suggests that they are T5-like phages of the Siphoviridae family. Among 
218 all the phages examined, phage AYO103A had the smallest head and shortest, non-contractile 219 tail and was characterized as T7-like phage of the Podoviridae family.

\section{Host range and lytic capability}

222

With the exception of serogroup O45, at least one strain from the other 8 serogroups of

223 non-O157 STEC tested was sensitive to one or more of the 11 phages studied. Excluding phages

224 AXO26A, AYO103A, AYO145A and AYO145B, all other phages were capable of lysing a

225 variety of strains across a range of non-O157 STEC serogroups (Table 1). Phages AYO26A,

226 AYO26B, AXO103A, AXO111A, AYO111A, AXO121A and AXO121B, respectively, lysed 11,

$22712,7,10,11,13$ and 8 of the 36 non-O157 STEC strains screened. Moreover, AYO26A,

228 AXO121A and AXO121B were also able to lyse common phage types $(2,8,14$ and 14a) of $E$.

229 coli $\mathrm{O} 157$ with moderate to extreme lytic capability.

Of the 10 STEC serogroups, O121-targeting phages (AXO121A and AXO121B) were

232 able to lyse at least one strain out of the 8 serogroups including O26, O103, O111, O121, O113,

233 O128, O91 and O157 with AXO121A showing broader host range and stronger lytic capability

234 than AXO121B. Of 18 STEC strains sensitive to AXO121A, 13 from serogroups O103 $(n=2)$,

235 O121 $(\mathrm{n}=4), \mathrm{O} 113(\mathrm{n}=1), \mathrm{O} 128(\mathrm{n}=2)$ and O157 $(\mathrm{n}=4)$ were classified as extremely

236 sensitive $(\mathrm{MOI}=0.00002-0.002)$ and 4 from serogroups O91 $(\mathrm{n}=2), \mathrm{O} 103(\mathrm{n}=1)$ and O157 $(\mathrm{n}$

$237=1)$ as highly sensitive $(\mathrm{MOI}=0.01-0.02)$ to phage.

Of O111-targeting phages, AXO111A and AYO111A displayed a similar host range and

240 lytic capability (average MOI, 0.6 vs 0.9) against serogroups O26, O111, O121, O128 and O145. 
241 Of the 21 sensitive strains to these phages, 5 from $\mathrm{O} 111$ and $\mathrm{O} 128,7$ from $\mathrm{O} 121$ and $\mathrm{O} 26$, and 9

242 from O26, O111, O121 and O145 were extremely, highly or moderately susceptible, respectively.

243 Host range and virulence of O26-targeting phages AXO26A, AYO26A and AYO26B were

244 variable, with AYO26A exhibiting the broadest host range and lowest MOI against serogroup

245 O26. AYO26A was also highly to extremely virulent to O145:NM and O103 strains $(\mathrm{MOI}=$

$2460.0009-0.8)$. In contrast, AYO26B only infected 2 bovine strains of serogroup O26, but this

247 phage was able to lyse 4 other non-O157 STEC serogroups including O111 (n=1), O121 (n=3),

$248 \mathrm{O} 145(\mathrm{n}=4)$ as well as $\mathrm{O} 128(\mathrm{n}=2)$. Consequently, this phage exhibited a host lytic profile that

249 was similar to AYO111A and AXO111A. Compared to AYO26A and AYO26B, host range of

250 AXO26A was more limited and restricted to 3 of 4 O26 strains.

\section{Phage genome sizing and RFLP analysis}

Phages all possessed double-stranded DNA genomes that ranged in size from 38 to

$254197 \mathrm{~kb}$ (Table 3). Within genera T4-, ViI- and T5-like phages, phage isolates shared a similar

255 genome size, whereas the genome size of O1-like phages differed with $89 \mathrm{~kb}$ for AYO145A,

$256 \quad 68 \mathrm{~kb}$ for AYO145B and $151 \mathrm{~kb}$ for AYO111A.

In general, the DNA of phage was more sensitive to digestion by EcoRV ( $\mathrm{n}=11)$, HaeII

$259(\mathrm{n}=9), \operatorname{EcoRI}(\mathrm{n}=8), \operatorname{XbaI}(\mathrm{n}=7)$ and HindIII $(\mathrm{n}=6)$ than Acc65II $(\mathrm{n}=4)$, BamHI $(\mathrm{n}=4)$,

$260 \operatorname{KpnI}(n=4)$, SacI $(n=1)$, SalI $(n=2)$ and PstI $(n=2)$ (Table 4). All phage DNA was resistant

261 to digestion by XhoI. The DNA of phages AXO26A, AXO103A, AYO103A and AXO121A

262 were fragmented by most of the restriction enzymes examined with AXO26A and AXO103A

263 sharing identical bands (Fig. 3A). Phages AYO26B, AXO111A, and AYO111A exhibited an 
264 85-89\% similar banding pattern after digestion with HaeII (Fig. 3B). In contrast, genomes of 265 phages AYO26A and AXO121B remained intact after exposure to Acc65I, BamHI, EcoRI, 266 HindIII, HaeII, KpnI, XbaI, SacI, SalI, PstI, XbaI and XhoI, but multiple restriction sites were 267 found after digestion with EcoRV (Fig. 3C).

\section{Discussion}

In the current study, 37 phages lytic to non-O157 STEC strains were isolated from cattle

271 fecal samples with further characterizing 11 of these. Based on TEM morphology, the 11 phage

272 isolates were classified into rV5-, T4-, ViI- and O1-like phages of the Myoviridae, T5-like

273 phages of the Siphoviridae and T7-like phages of the Podoviridae. The diversity of phages

274 isolated may reflect the fact that fecal samples originated from livestock trailers which housed up

275 to 47 of head of cattle transported from a diversity of geographical locations within western

276 Canada. Viscardi et al. (2008) reported that two T4-like O157-infecting phages, isolated from

277 bovine feces in Italy, were able to lyse serotypes O111, O113, O121 and O145 of non-O157

278 STEC, whereas Dini and Urraza (2010) found O113 phages of Myoviridae and O157 phages of

279 Myoviridae and Podoviridae with activity against serotypes O103, O113 and O145 from bovine

280 feces in Argentina. Accordingly, results of this study may indicate that non-O157 STEC

281 infecting phages are ubiquitous in cattle. Moreover, multiple phages targeting various non-O157

282 STEC serogroups were recovered simultaneously from the same load of cattle. This observation

283 is in agreement with the observation that a diversity of non-O157 STEC serogroups was also

284 isolated from the same load of cattle (Stanford et al, unpublished data). Probability of phage

285 isolation increases with the presence of a susceptible host and consequently bovine feces that

286 contains higher numbers of non-O15 STEC is also likely to be source of phages (Niu et al. 
287 2009a). In the present study, phages with activity against serogroup O45 were not isolated, 288 possibly as this serogroup was detected in only $12.6 \%$ of samples collected from May 2013 to 289 August 2013 (Stanford et al, unpublished data). Furthermore, the four strains of O45 evaluated 290 were resistant to all 11 phage isolates, suggesting that these phages lacked the receptor for 291 recognition and binding to the O45 serogroup. AXO121B exhibited a relatively broad host range as they lysed clinically important non-O157

295 STEC strains from multiple serogroups (O26, O91, O103, O111, O113, O121, O128 and O145) associated with mild to severe disease in humans (Johnson et al. 2006; Bettelheim 2007). Moreover, AYO26A, AXO121A and AXO121B were also able to infect several of the common phage types of $E$. coli $\mathrm{O} 157: \mathrm{H} 7$ (2, 8, 14 and 14a). The receptor binding proteins in phages are

299 physically located on the long tail fibers and/or short tail spikes and interact specifically with 300 receptors on the surface of the host cell (Marti et al. 2013; Samson et al. 2013). Different surface 301 components have been identified as receptors for phages in bacteria, including the flagella, pili,

302 lipopolysaccharides, capsular polysaccharides, teichoic acid, and outer member proteins (Hyman 303 and Abedon 2010; Rakhuba et al. 2010). The lipopolysaccharide is composed of a lipid A

304 anchored in the membrane, an oligosaccharide core and $\mathrm{O}$-polysaccharide ( $\mathrm{O}$ antigen) (Erridge et 305 al. 2002). Among these receptors, $\mathrm{O}$ antigen of the lipopolysaccharides is considered to be a 306 common receptor recognized by phages. Accordingly, the broad host range of phages AYO26A, 307 AYO26B, AXO103A, AXO111A, AYO111A, AXO121A and AXO121B likely reflects their 308 ability to target a common outer membrane protein or lipopolysaccharides region among 309 susceptible strains. Some phages may also exhibit broader host spectrum by possessing more 
310 than one receptor binding protein as is the case for the T7-like phage K1-5 which has two

311 different receptor binding proteins enabling recognition and attachment to both $E$. coli $\mathrm{K} 1$ and $E$.

312 coli K5 (Leiman et al. 2007). Schwarzer et al. (2012) found that the broad host range of rV5-like

313 phage phi92 was a result of the presence of four different types of tail fibers and/or tail spikes

314 that enabled this phage to infect both encapsulated and non-encapsulated bacteria including

315 several strains of E. coli and Salmonella.

In addition, isolated phages varied in lytic capabilities both within and among non-O157

318 STEC serogroups. In general, a lower MOI was found for the serogroup of the non-O157 STEC

319 strain originally used to isolate the phage as compared to susceptible strains from other

320 serogroups. For example, phage AYO26A was extremely lytic against E. coli strains within the

321 O26 serogroup $(\mathrm{MOI}=0.000006-0.0007)$ with the exception of the $\mathrm{O} 26$ reference strain

322 EC19930517 which was moderately susceptible to AYO26A (MOI = 1). Likely, physiological

323 growth parameters of the phages such as adsorption rate, latent period and burst size differ from

324 strain to strain within the same serogroup (Diaz-Munoz and Koskella 2014).

325

Phages AYO111A, AYO145A and AYO145B exhibited morphotypes characteristic of

327 O1-like phages, but varied in genome size. The genome of O1-like phages previously identified 328 ranged from 85 to $88 \mathrm{~kb}$ (Lehman et al. 2009; Villegas et al. 2009; Whichard et al. 2010),

329 whereas the genome of AYO145A and AYO111A were 68 and $151 \mathrm{~kb}$, respectively. More

330 interestingly, O1-like phages AYO111A displayed a morphology and host range similar to the

331 ViI-like phages, a phenotype that agrees with their similar genome sizes and RFLP profiles. 
332 Further genome sequencing would reveal the degree of genetic relatedness among O1-like and

333 ViI-like phages.

334

335

O26 phage AXO26A and O103 phage AXO103A, simultaneously isolated from the same

336 fecal sample, were T5-like phages with the same genome size and identical DNA restriction

337 profiles. However, their host range differed with AXO103A exhibiting activity against both

338 serogroups $\mathrm{O} 26$ and $\mathrm{O} 103$ and AXO26A being infective only to O26. This suggests that

339 although the genomes of AXO26A and AXO103A share similarities, there may be coding

340 difference in long tail fibers and/or receptor binding proteins.

Of the 10 restriction enzymes tested, DNA of T4-like phages (AYO26A and AXO121B)

343 was only digested by EcoRV, a result similar to that of T4-like E. coli O157-infecting phages

344 (Raya et al. 2006; Hallewell et al. 2014). Most endonucleases do not digest T4-DNA, possibly

345 due to the presence of glycosylated hydroxylmethyl cytosine instead of cytosine (Miller et al.,

346 2003). This modification allows T4 DNA to be impervious to restriction-modification (R-M)

347 systems that recognize specific sequences containing a cytosine (Labrie et al. 2010). Restriction-

348 modification is one of strategies that bacterial cells utilize to guard against phage infection. As a

349 result of their resistance to most restriction enzymes, T4-like phages may be more infective to

350 STEC and thereby superior candidates for phage-based biocontrol strategies.

352 In conclusion, various types of phages from 6 genera across three Myoviridae,

353 Siphoviridae and Podoviridae families were isolated from the feces of feedlot cattle. Multiple

354 phages targeting different serogroups of non-O157 STEC were detected within feces collected 
355 from the same trailer. Phages with infectivity against at least one isolate from STEC serogroups 356 O26, O91, O103, O111, O113, O121, O128 and O145 were identified. As non-O157 STEC are a

357 non-homogenous group, it is not surprising that none of the phages were able to infect all non358 O157 STEC serogroups and a cocktail of phages will likely be required for controlling the "top 359 6" non-O157 STEC. As phages AYO26A, AYO26B, AXO103A, AXO111A, AYO111A, 360 AXO121A and AXO121B exhibited a wide host range against a number of STEC serogroups, 361 including $\mathrm{O} 157: \mathrm{H7}$, these phages may be most appropriate for future use in a STEC biocontrol 362 strategy.

363 Acknowledgements

365 This project was financially supported in part by Growing Forward 2, a federal-

366 provincial-territorial initiative as well as China Scholarship Council (MOE-AAFC-PhD Research

367 Program). We gratefully acknowledge R. Barbieri, S. Cook and C. Klima from AAFC and J.

368 Peters, S. Trapp and Y. Han from AARD for technical assistance and support. 369

370 


\section{References}

372 Abuladze, T., Li, M., Menetrez, M.Y., Dean, T., Senecal, A. and Sulakvelidze, A. 2008.

373 Bacteriophages reduce experimental contamination of hard surfaces, tomato, spinach,

$374 \quad$ broccoli, and ground beef by Escherichia coli O157:H7. Appl. Environ. Microbiol.

$375 \quad 74(20): 6230-6238$.

376 Ackermann, H.W. 2007. Salmonella phages examined in the electron microscope. Methods Mol.

$377 \quad$ Biol. 394: 213-234.

378 Ackermann, H.W., Berthiaume, L. and Kasatiya, S.S. 1970. Ultrastructure of Vi phages I to VII

379 of Salmonella typhi. Can. J. Microbiol. 16(6): 411-413.

380 Bettelheim, K.A. 2007. The non-O157 shiga-toxigenic (verocytotoxigenic) Escherichia coli;

381 under-rated pathogens. Crit. Rev. Microbiol. 33(1): 67-87.

382 Callaway, T.R., Edrington, T.S., Brabban, A.D., Anderson, R.C., Rossman, M.L., Engler, M.J.,

383 Carr, M.A., Genovese, K.J., Keen, J.E., Looper, M.L., Kutter, E.M. and Nisbet, D.J. 2008.

$384 \quad$ Bacteriophage isolated from feedlot cattle can reduce Escherichia coli $\mathrm{O} 157: \mathrm{H} 7$

385 populations in ruminant gastrointestinal tracts. Foodborne Pathog. Dis. 5(2): 183-191.

386 Carter, C.D., Parks, A., Abuladze, T., Li, M., Woolston, J., Magnone, J., Senecal, A., Kropinski,

387 A.M. and Sulakvelidze, A. 2012. Bacteriophage cocktail significantly reduces

388 Escherichia coli O157: H7 contamination of lettuce and beef, but does not protect against

389 recontamination. Bacteriophage 2(3): 178-185.

390 Diaz-Munoz, S.L. and Koskella, B. 2014. Bacteria-phage interactions in natural environments.

391 Adv. Appl. Microbiol. 89: 135-183. 
392 Dini, C. and De Urraza, P.J. 2010. Isolation and selection of coliphages as potential biocontrol 393 agents of enterohemorrhagic and Shiga toxin-producing E. coli (EHEC and STEC) in cattle. J. Appl. Microbiol. 109(3): 873-887.

Erridge, C., Bennett-Guerrero, E. and Poxton, I.R. 2002. Structure and function of lipopolysaccharides. Microbes Infect. 4(8): 837-851.

Ethelberg, S., Smith, B., Torpdahl, M., Lisby, M., Boel, J., Jensen, T., et al. 2009. Outbreak of non-O157 Shiga toxin-producing Escherichia coli infection from consumption of beef sausage. Clin. Infect. Dis. 48(8): e78-81.

Hallewell, J., Niu, Y.D., Munns, K., McAllister, T.A., Johnson, R.P., Ackermann, H.W., et al. 2014. Differing populations of endemic bacteriophages in cattle shedding high and low numbers of Escherichia coli O157:H7 bacteria in feces. Appl. Environ. Microbiol. 80(13): $3819-3825$.

Hermos, C.R., Janineh, M., Han, L.L. and McAdam, A.J. 2011. Shiga toxin-producing Escherichia coli in children: diagnosis and clinical manifestations of O157:H7 and nonO157:H7 infection. J. Clin. Microbiol. 49(3): 955-959.

Hong, Y., Pan, Y. and Ebner, P.D. 2014. Meat Science and Muscle Biology Symposium:

410 Hussein, H.S. and Bollinger, L.M. 2005. Prevalence of Shiga toxin-producing Escherichia coli in beef cattle. J. Food Prot. 68(10): 2224-2241.

412 Hyman, P. and Abedon, S.T. 2010. Bacteriophage host range and bacterial resistance. Adv. Appl. Microbiol.70: 217-248. 
414 Johnson, K.E., Thorpe, C.M. and Sears, C.L. 2006. The emerging clinical importance of non415 O157 Shiga toxin-producing Escherichia coli. Clin. Infect. Dis. 43(12): 1587-1595.

416 Kropinski, A.M., Waddell, T., Meng, J., Franklin, K., Ackermann, H.W., Ahmed, R., et al. 2013.

417 The host-range, genomics and proteomics of Escherichia coli O157:H7 bacteriophage $418 \quad$ rV5. Virol. J. 10: 76.

419 Kutateladze, M. and Adamia, R. 2010. Bacteriophages as potential new therapeutics to replace or $420 \quad$ supplement antibiotics. Trends. Biotechnol. 28(12): 591-595.

421 Kutter, E.M., Skutt-Kakaria, K., Blasdel, B., El-Shibiny, A., Castano, A., Bryan, D., et al. 2011. $422 \quad$ Characterization of a ViI-like phage specific to Escherichia coli O157:H7. Virol. J. 8: 430.

424 Labrie, S.J., Samson, J.E. and Moineau, S. 2010. Bacteriophage resistance mechanisms. Nat. Rev. 425 Microbiol. 8(5): 317-327.

426 Lehman, S.M., Kropinski, A.M., Castle, A.J. and Svircev, A.M. 2009. Complete genome of the 427 broad-host-range Erwinia amylovora phage $\phi E a 21-4$ and its relationship to Salmonella

Leiman, P.G., Battisti, A.J., Bowman, V.D., Stummeyer, K., Muhlenhoff, M., Gerardy-Schahn, R., Scholl, D. and Molineux, I.J. 2007. The structures of bacteriophages K1E and K1-5

Lingohr, E., Frost, S. and Johnson, R.P. 2009. Determination of bacteriophage genome size by pulsed-field gel electrophoresis. Methods. Mol. Biol. 502: 19-25. 
435 Luna-Gierke, R.E., Griffin, P.M., Gould, L.H., Herman, K., Bopp, C.A., Strockbine, N. and 436 Mody, R.K. 2014. Outbreaks of non-O157 Shiga toxin-producing Escherichia coli agents of food pathogens. Curr. Opin. Biotechnol. 22(2): 157-163.

Marti, R., Zurfluh, K., Hagens, S., Pianezzi, J., Klumpp, J. and Loessner, M.J. 2013. Long tail fibres of the novel broad-host-range T-even bacteriophage S16 specifically recognize Salmonella OmpC. Mol. Microbiol. 87(4): 818-834.

Mathusa, E.C., Chen, Y., Enache, E. and Hontz, L. 2010. Non-O157 Shiga toxin-producing Escherichia coli in foods. J. Food. Prot. 73(9): 1721-1736.

Miller, E.S., Kutter, E., Mosig, G., Arisaka, F., Kunisawa, T., and Ruger, W. 2003. Bacteriophage T4 genome. Microbiol. Mo.1 Biol. Rev. 67(1): 86-156.

Niu, Y.D., McAllister, T.A., Xu, Y., Johnson, R.P., Stephens, T.P. and Stanford, K. 2009a.

Niu, Y.D., Johnson, R.P., Xu, Y., McAllister, T.A., Sharma, R., Louie, M. and Stanford, K. 2009b. Host range and lytic capability of four bacteriophages against bovine and clinical Prevalence and impact of bacteriophages on the presence of Escherichia coli O157:H7 in

Niu, Y.D., Stanford, K., Ackermann, H.W. and McAllister, T.A. 2012. Characterization of 4 T1human isolates of Shiga toxin-producing Escherichia coli O157:H7. J. Appl. Microbiol. like lytic bacteriophages that lyse Shiga-toxin Escherichia coli O157:H7. Can. J. Microbiol. 58(7): 923-927. 
457 Pickard, D., Toribio, A.L., Petty, N.K., van Tonder, A., Yu, L., Goulding, D., Barrell, B., et al.

458 2010. A conserved acetyl esterase domain targets diverse bacteriophages to the Vi capsular receptor of Salmonella enterica serovar Typhi. J. Bacteriol. 192(21): 5746-5754.

Poole, K. 2003. Overcoming multidrug resistance in gram-negative bacteria. Curr. Opin. Investig. Drugs 4(2): 128-139.

Rakhuba, D.V., Kolomiets, E.I., Dey, E.S. and Novik, G.I. 2010. Bacteriophage receptors, mechanisms of phage adsorption and penetration into host cell. Pol. J. Microbiol. 59(3): $145-155$.

Raya, R.R., Oot, R.A., Moore-Maley, B., Wieland, S., Callaway, T.R., Kutter, E.M. and Brabban, A.D. 2011. Naturally resident and exogenously applied T4-like and T5-like bacteriophages can reduce Escherichia coli O157:H7 levels in sheep guts. Bacteriophage 1(1): 15-24.

Raya, R.R., Varey, P., Oot, R.A., Dyen, M.R., Callaway, T.R., Edrington, T.S., et al. 2006. Isolation and characterization of a new T-even bacteriophage, CEV1, and determination of its potential to reduce Escherichia coli O157:H7 levels in sheep. Appl. Environ. Microbiol. 72(9): 6405-6410.

Robbins, A., Anand, M., Nicholas, D.C., Egan, J.S., Musser, K.A., Giguere, S., et al. 2014. Ground beef recall associated with non-O157 Shiga toxin-producing Escherichia coli, United States. Emerg. Infect. Dis. 20(1): 165-167.

Sambrook J., Russell D.W. 2001. Molecular cloning: a laboratory manul. 3 rd ed., Cold Spring Harbor Laboratory Press. Cold Spring Harbor, N.Y. USA.

Samson, J.E., Magadan, A.H., Sabri, M. and Moineau, S. 2013. Revenge of the phages: defeating bacterial defences. Nat. Rev. Microbiol. 11(10): 675-687. 
480 Schwarzer, D., Buettner, F.F., Browning, C., Nazarov, S., Rabsch, W., Bethe, A., et al. 2012. A 481 multivalent adsorption apparatus explains the broad host range of phage phi92: a comprehensive genomic and structural analysis. J. Virol. 86(19): 10384-10398.

Sheng, H., Knecht, H.J., Kudva, I.T. and Hovde, C.J. 2006. Application of bacteriophages to control intestinal Escherichia coli O157:H7 levels in ruminants. Appl. Environ.

Smith, J.L., Fratamico, P.M. and Gunther, N.W. 2014. Shiga toxin-producing Escherichia coli. Adv. Appl. Microbiol. 86: 145-197.

USDA .2012. Shiga toxin-producing Escherichia coli in certain raw beef products. Fed. Reg. 77: $31975-31981$.

Villegas, A., She, Y.M., Kropinski, A.M., Lingohr, E.J., Mazzocco, A., Ojha, S., et al. 2009. The genome and proteome of a virulent Escherichia coli $\mathrm{O} 157: \mathrm{H} 7$ bacteriophage closely resembling Salmonella phage Felix O1. Virol. J. 6: 41.

Viscardi, M., Perugini, A.G., Auriemma, C., Capuano, F., Morabito, S., Kim, K.-P., et al. 2008. Isolation and characterisation of two novel coliphages with high potential to control antibiotic-resistant pathogenic Escherichia coli (EHEC and EPEC). Int. J. Antimicrob. Ag. 31(2): 152-157.

Wang, F., Yang, Q., Kase, J.A., Meng, J., Clotilde, L.M., Lin, A. and Ge, B. 2013. Current trends in detecting non-O157 Shiga toxin-producing Escherichia coli in food. Foodborne Pathog. Dis. 10(8): 665-677.

Weinbauer M.G. 2004 Ecology of prokaryotic viruses. FEMS Microbiol. Rev. 28(2), 127-181.

Whichard, J.M., Weigt, L.A., Borris, D.J., Li, L.L., Zhang, Q., Kapur, V., Pierson, F.W., et al. 2010. Complete genomic sequence of bacteriophage felix o1. Viruses 2(3): 710-730. 
Table 1 Host range and lytic capability of 11 non-O157 STEC phages

\begin{tabular}{|c|c|c|c|c|c|c|c|c|c|c|c|c|c|}
\hline \multirow{3}{*}{ Serogroups } & \multirow{3}{*}{ Source $^{*}$} & \multirow{3}{*}{ Strain Ref.NO.(PT) ${ }^{\dagger}$} & \multicolumn{11}{|c|}{ Sensitivity to phages } \\
\hline & & & \multicolumn{3}{|c|}{ O26 phages } & \multicolumn{2}{|c|}{ O103 phages } & \multicolumn{2}{|c|}{ O111 phages } & \multicolumn{2}{|l|}{ O121 phages } & \multicolumn{2}{|c|}{ O145 phages } \\
\hline & & & $\mathrm{AXO} 26 \mathrm{~A}$ & $\mathrm{AYO} 26 \mathrm{~A}$ & $\mathrm{AYO} 26 \mathrm{~B}$ & AXO103A & AYO103A & AXO111A & AYO111A & AXO121A & AXO121B & AYO145A & AYO145B \\
\hline $\mathrm{O} 26: \mathrm{H} 11$ & B & EC19930517 & $\mathrm{R}$ & 1 & 4 & $\mathrm{R}$ & $\mathrm{R}$ & $\mathrm{R}$ & $\mathrm{R}$ & $\mathrm{R}$ & $\mathrm{R}$ & $\mathrm{R}$ & $\mathrm{R}$ \\
\hline $\mathrm{O} 26: \mathrm{H} 11$ & $\mathrm{~B}$ & EC19960464 & $9 \times 10^{-5}$ & $7 \times 10^{-4}$ & $2 \times 10^{-1}$ & $4 \times 10^{-3}$ & $\mathrm{R}$ & $1 \times 10^{-1}$ & $2 \times 10^{-1}$ & $\mathrm{R}$ & $\mathrm{R}$ & $\mathrm{R}$ & $\mathrm{R}$ \\
\hline $\mathrm{O} 26: \mathrm{H} 11$ & $\mathrm{H}$ & EC19970119 & $8 \times 10^{-2}$ & $6 \times 10^{-6}$ & $\mathrm{R}$ & $3 \times 10^{-2}$ & $\mathrm{R}$ & $\mathrm{R}$ & $\mathrm{R}$ & $\mathrm{R}$ & 6 & $\mathrm{R}$ & $\mathrm{R}$ \\
\hline $\mathrm{O} 26: \mathrm{H} 11$ & $\mathrm{H}$ & EC19990859 & 1 & $1 \times 10^{-5}$ & $\mathrm{R}$ & $6 \times 10^{-2}$ & $\mathrm{R}$ & $\mathrm{R}$ & 2 & $\mathrm{R}$ & $\mathrm{R}$ & $\mathrm{R}$ & $\mathrm{R}$ \\
\hline $\mathrm{O} 45: \mathrm{H} 2$ & $\mathrm{~B}$ & EC19940040 & $\mathrm{R}$ & $\mathrm{R}$ & $\mathrm{R}$ & $\mathrm{R}$ & $\mathrm{R}$ & $\mathrm{R}$ & $\mathrm{R}$ & $\mathrm{R}$ & $\mathrm{R}$ & $\mathrm{R}$ & $\mathrm{R}$ \\
\hline $\mathrm{O} 45: \mathrm{H} 2$ & $\mathrm{H}$ & EC19970074 & $\mathrm{R}$ & $\mathrm{R}$ & $\mathrm{R}$ & $\mathrm{R}$ & $\mathrm{R}$ & $\mathrm{R}$ & $\mathrm{R}$ & $\mathrm{R}$ & $\mathrm{R}$ & $\mathrm{R}$ & $\mathrm{R}$ \\
\hline $\mathrm{O} 45: \mathrm{H} 2$ & $\mathrm{H}$ & EC19970086 & $\mathrm{R}$ & $\mathrm{R}$ & $\mathrm{R}$ & $\mathrm{R}$ & $\mathrm{R}$ & $\mathrm{R}$ & $\mathrm{R}$ & $\mathrm{R}$ & $\mathrm{R}$ & $\mathrm{R}$ & $\mathrm{R}$ \\
\hline $\mathrm{O} 45: \mathrm{H} 2$ & $\mathrm{H}$ & EC19970358 & $\mathrm{R}$ & $\mathrm{R}$ & $\mathrm{R}$ & $\mathrm{R}$ & $\mathrm{R}$ & $\mathrm{R}$ & $\mathrm{R}$ & $\mathrm{R}$ & $\mathrm{R}$ & $\mathrm{R}$ & $\mathrm{R}$ \\
\hline O103:H2 & $\mathrm{B}$ & EC19970327 & $\mathrm{R}$ & $1 \times 10^{-3}$ & $\mathrm{R}$ & $7 \times 10^{-2}$ & $\mathrm{R}$ & $\mathrm{R}$ & $\mathrm{R}$ & $1 \times 10^{-3}$ & $\mathrm{R}$ & $\mathrm{R}$ & $\mathrm{R}$ \\
\hline $\mathrm{O} 103: \mathrm{H} 2$ & $\mathrm{H}$ & EC19970345 & $\mathrm{R}$ & $1 \times 10^{-3}$ & $\mathrm{R}$ & $7 \times 10^{-2}$ & $\mathrm{R}$ & $\mathrm{R}$ & $\mathrm{R}$ & $2 \times 10^{-3}$ & $\mathrm{R}$ & $\mathrm{R}$ & $\mathrm{R}$ \\
\hline $\mathrm{O} 103: \mathrm{H} 2$ & $\mathrm{~B}$ & EC20010670 & $\mathrm{R}$ & $1 \times 10^{-3}$ & $\mathrm{R}$ & $9 \times 10^{-2}$ & 7 & $\mathrm{R}$ & $\mathrm{R}$ & $\mathrm{R}$ & $\mathrm{R}$ & $\mathrm{R}$ & $\mathrm{R}$ \\
\hline $\mathrm{O} 103: \mathrm{H} 2$ & $\mathrm{H}$ & EC20020219 & $\mathrm{R}$ & $9 \times 10^{-4}$ & $\mathrm{R}$ & $1 \times 10^{-2}$ & $\mathrm{R}$ & $\mathrm{R}$ & $\mathrm{R}$ & $1 \times 10^{-2}$ & $\mathrm{R}$ & $\mathrm{R}$ & $\mathrm{R}$ \\
\hline O111:H8 & $\mathrm{B}$ & EC19930467 & $\mathrm{R}$ & $\mathrm{R}$ & $\mathrm{R}$ & $\mathrm{R}$ & $\mathrm{R}$ & $\mathrm{R}$ & $\mathrm{R}$ & $\mathrm{R}$ & $\mathrm{R}$ & $\mathrm{R}$ & $\mathrm{R}$ \\
\hline O111:H8 & $\mathrm{B}$ & EC20000612 & $\mathrm{R}$ & $\mathrm{R}$ & $\mathrm{R}$ & $\mathrm{R}$ & $\mathrm{R}$ & 2 & 3 & $\mathrm{R}$ & $\mathrm{R}$ & $\mathrm{R}$ & $\mathrm{R}$ \\
\hline O111:NM & $\mathrm{H}$ & EC20000927 & $\mathrm{R}$ & $\mathrm{R}$ & $\mathrm{R}$ & $\mathrm{R}$ & $\mathrm{R}$ & $\mathrm{R}$ & $\mathrm{R}$ & $\mathrm{R}$ & $\mathrm{R}$ & $\mathrm{R}$ & $\mathrm{R}$ \\
\hline O111:NM & $\mathrm{B}$ & EC20030053 & $\mathrm{R}$ & $\mathrm{R}$ & $4 \times 10^{-3}$ & $\mathrm{R}$ & $\mathrm{R}$ & $2 \times 10^{-3}$ & $3 \times 10^{-4}$ & 2 & $\mathrm{R}$ & $\mathrm{R}$ & $\mathrm{R}$ \\
\hline O121:H19 & $\mathrm{H}$ & EC19960807 & $\mathrm{R}$ & $\mathrm{R}$ & $4 \times 10^{-1}$ & $\mathrm{R}$ & $\mathrm{R}$ & $1 \times 10^{-1}$ & $2 \times 10^{-1}$ & $2 \times 10^{-4}$ & $1 \times 10^{-1}$ & $\mathrm{R}$ & $\mathrm{R}$ \\
\hline O121:H19 & $\mathrm{H}$ & EC19990161 & $\mathrm{R}$ & $\mathrm{R}$ & $\mathrm{R}$ & $\mathrm{R}$ & $\mathrm{R}$ & $\mathrm{R}$ & $\mathrm{R}$ & $1 \times 10^{-5}$ & $9 \times 10^{-3}$ & $\mathrm{R}$ & $\mathrm{R}$ \\
\hline O121:H19 & $\mathrm{H}$ & EC20020234 & $\mathrm{R}$ & $\mathrm{R}$ & $3 \times 10^{-1}$ & $\mathrm{R}$ & $\mathrm{R}$ & 1 & $2 \times 10^{-1}$ & $1 \times 10^{-3}$ & 1 & $\mathrm{R}$ & $\mathrm{R}$ \\
\hline O121:H19 & $\mathrm{B}$ & EC20040083 & $\mathrm{R}$ & $\mathrm{R}$ & $3 \times 10^{-1}$ & $\mathrm{R}$ & $\mathrm{R}$ & 1 & $2 \times 10^{-1}$ & $1 \times 10^{-4}$ & $1 \times 10^{-1}$ & $\mathrm{R}$ & $\mathrm{R}$ \\
\hline O145:NM & $\mathrm{H}$ & EC19970355 & $\mathrm{R}$ & $1 \times 10^{-1}$ & 3 & $\mathrm{R}$ & $\mathrm{R}$ & $\mathrm{R}$ & $\mathrm{R}$ & $\mathrm{R}$ & $\mathrm{R}$ & $9 \times 10^{-1}$ & $1 \times 10^{-1}$ \\
\hline $\mathrm{O} 145: \mathrm{H} 25$ & $\mathrm{H}$ & EC19990166 & $\mathrm{R}$ & $\mathrm{R}$ & 4 & $\mathrm{R}$ & $\mathrm{R}$ & 1 & $\mathrm{R}$ & $\mathrm{R}$ & $\mathrm{R}$ & $\mathrm{R}$ & $\mathrm{R}$ \\
\hline O145:NM & $\mathrm{H}$ & EC19990324 & $\mathrm{R}$ & $8 \times 10^{-1}$ & 3 & $\mathrm{R}$ & $\mathrm{R}$ & 1 & 2 & $\mathrm{R}$ & $\mathrm{R}$ & $8 \times 10^{-1}$ & $9 \times 10^{-1}$ \\
\hline O145:NM & $\mathrm{H}$ & EC20020231 & $\mathrm{R}$ & $8 \times 10^{-1}$ & 4 & $\mathrm{R}$ & $\mathrm{R}$ & $\mathrm{R}$ & 3 & $\mathrm{R}$ & $\mathrm{R}$ & $8 \times 10^{-2}$ & $9 \times 10^{-1}$ \\
\hline $\mathrm{O} 113: \mathrm{H} 4$ & $\mathrm{~B}$ & EC19960371 & $\mathrm{R}$ & $\mathrm{R}$ & $\mathrm{R}$ & $\mathrm{R}$ & $\mathrm{R}$ & $\mathrm{R}$ & $\mathrm{R}$ & $\mathrm{R}$ & $\mathrm{R}$ & $\mathrm{R}$ & $\mathrm{R}$ \\
\hline O113:H4 & $\mathrm{B}$ & EC19960434 & $\mathrm{R}$ & $\mathrm{R}$ & $\mathrm{R}$ & $\mathrm{R}$ & $\mathrm{R}$ & $\mathrm{R}$ & $\mathrm{R}$ & $\mathrm{R}$ & $\mathrm{R}$ & $\mathrm{R}$ & $\mathrm{R}$ \\
\hline O113:H21 & $\mathrm{H}$ & EC19970352 & $\mathrm{R}$ & $\mathrm{R}$ & $\mathrm{R}$ & $\mathrm{R}$ & $\mathrm{R}$ & $\mathrm{R}$ & $\mathrm{R}$ & $\mathrm{R}$ & $7 \times 10^{-4}$ & $\mathrm{R}$ & $\mathrm{R}$ \\
\hline $\mathrm{O} 113: \mathrm{H} 21$ & $\mathrm{H}$ & EC20020170 & $\mathrm{R}$ & $\mathrm{R}$ & $\mathrm{R}$ & $\mathrm{R}$ & $\mathrm{R}$ & $\mathrm{R}$ & $\mathrm{R}$ & $1 \times 10^{-3}$ & $9 \times 10^{-3}$ & $\mathrm{R}$ & $\mathrm{R}$ \\
\hline O128:NM & $\mathrm{H}$ & EC19960949 & $\mathrm{R}$ & $\mathrm{R}$ & $6 \times 10^{-4}$ & $\mathrm{R}$ & $\mathrm{R}$ & $2 \times 10^{-4}$ & $4 \times 10^{-4}$ & $3 \times 10^{-4}$ & $\mathrm{R}$ & $\mathrm{R}$ & $\mathrm{R}$ \\
\hline $\mathrm{O} 128: \mathrm{H} 2$ & $\mathrm{H}$ & EC19990162 & $\mathrm{R}$ & $\mathrm{R}$ & 2 & $\mathrm{R}$ & $\mathrm{R}$ & $1 \times 10^{-2}$ & $4 \times 10^{-3}$ & $1 \times 10^{-4}$ & $\mathrm{R}$ & $\mathrm{R}$ & $\mathrm{R}$ \\
\hline O128:H10 & $\mathrm{H}$ & EC20000914 & $\mathrm{R}$ & $\mathrm{R}$ & $\mathrm{R}$ & $\mathrm{R}$ & $\mathrm{R}$ & $\mathrm{R}$ & $\mathrm{R}$ & $\mathrm{R}$ & $\mathrm{R}$ & $\mathrm{R}$ & $\mathrm{R}$ \\
\hline O128:NM & $\mathrm{H}$ & EC20100049 & $\mathrm{R}$ & $\mathrm{R}$ & $\mathrm{R}$ & $\mathrm{R}$ & $\mathrm{R}$ & $\mathrm{R}$ & $\mathrm{R}$ & $\mathrm{R}$ & $\mathrm{R}$ & $\mathrm{R}$ & $\mathrm{R}$ \\
\hline O91:NM & $\mathrm{O}$ & EC19950329 & $\mathrm{R}$ & $\mathrm{R}$ & $\mathrm{R}$ & $\mathrm{R}$ & $\mathrm{R}$ & $\mathrm{R}$ & $\mathrm{R}$ & $1 \times 10^{-2}$ & $\mathrm{R}$ & $\mathrm{R}$ & $\mathrm{R}$ \\
\hline O91:NM & $\mathrm{O}$ & EC19950340 & $\mathrm{R}$ & $\mathrm{R}$ & $\mathrm{R}$ & $\mathrm{R}$ & $\mathrm{R}$ & $\mathrm{R}$ & $\mathrm{R}$ & $\mathrm{R}$ & $\mathrm{R}$ & $\mathrm{R}$ & $\mathrm{R}$ \\
\hline O91:H21 & $\mathrm{H}$ & EC20010076 & $\mathrm{R}$ & $\mathrm{R}$ & $\mathrm{R}$ & $\mathrm{R}$ & $\mathrm{R}$ & $\mathrm{R}$ & $\mathrm{R}$ & $\mathrm{R}$ & $\mathrm{R}$ & $\mathrm{R}$ & $\mathrm{R}$ \\
\hline O91:H21 & $\mathrm{B}$ & EC20020030 & $\mathrm{R}$ & $\mathrm{R}$ & $\mathrm{R}$ & $\mathrm{R}$ & $\mathrm{R}$ & $\mathrm{R}$ & $\mathrm{R}$ & $2 \times 10^{-1}$ & 7 & $\mathrm{R}$ & $\mathrm{R}$ \\
\hline $\mathrm{O} 157: \mathrm{H} 7$ & $\mathrm{~B}$ & R508(14) & $\mathrm{R}$ & 1 & $\mathrm{R}$ & $\mathrm{R}$ & $\mathrm{R}$ & $\mathrm{R}$ & $\mathrm{R}$ & $2 \times 10^{-5}$ & $\mathrm{R}$ & $\mathrm{R}$ & $\mathrm{R}$ \\
\hline $\mathrm{O} 157: \mathrm{H} 7$ & $\mathrm{~B}$ & EC20110007(14a) & $\mathrm{R}$ & $8 \times 10^{-1}$ & $\mathrm{R}$ & $\mathrm{R}$ & $\mathrm{R}$ & $\mathrm{R}$ & $\mathrm{R}$ & $1 \times 10^{-3}$ & $\mathrm{R}$ & $\mathrm{R}$ & $\mathrm{R}$ \\
\hline $\mathrm{O} 157: \mathrm{H} 7$ & $\mathrm{H}$ & EC19990298(14) & $\mathrm{R}$ & $7 \times 10^{-2}$ & $\mathrm{R}$ & $\mathrm{R}$ & $\mathrm{R}$ & $\mathrm{R}$ & $\mathrm{R}$ & $1 \times 10^{-4}$ & 7 & $\mathrm{R}$ & $\mathrm{R}$ \\
\hline $\mathrm{O} 157: \mathrm{H} 7$ & $\mathrm{H}$ & EC19990300(2) & $\mathrm{R}$ & $9 \times 10^{-2}$ & $\mathrm{R}$ & $\mathrm{R}$ & $\mathrm{R}$ & $\mathrm{R}$ & $\mathrm{R}$ & $1 \times 10^{-4}$ & 9 & $\mathrm{R}$ & $\mathrm{R}$ \\
\hline O157:H7 & $\mathrm{H}$ & EC20110005(8) & $\mathrm{R}$ & $1 \times 10^{-1}$ & $\mathrm{R}$ & $\mathrm{R}$ & $\mathrm{R}$ & $\mathrm{R}$ & $\mathrm{R}$ & $2 \times 10^{-2}$ & 13 & $\mathrm{R}$ & $\mathrm{R}$ \\
\hline
\end{tabular}

* STEC strains isolated from, B: bovine; H: human; O: ovine.

${ }^{\dagger} \mathrm{PT}$, phages types of STEC O157:H7.

\$ Sensitivity is based on multiplicity of infection (the lowest ratio of phage to bacteria that resulted in complete lysis of an overnight bacterial culture after $5 \mathrm{~h}$ of incubation).

$\mathrm{R}$, no lysis observed.

503 
504

Table 2 Sampling information of 11 non-O157 STEC-infecting phages

\begin{tabular}{|c|c|c|c|c|c|c|}
\hline \multirow[b]{2}{*}{$\begin{array}{l}\text { Phage } \\
\text { isolates }\end{array}$} & \multirow[b]{2}{*}{$\begin{array}{l}\text { Targeting } \\
\text { serogroups }\end{array}$} & \multicolumn{4}{|l|}{ Origin } & \multirow[b]{2}{*}{$\begin{array}{l}\text { Sampling } \\
\text { date }\end{array}$} \\
\hline & & $\begin{array}{l}\text { Geographical } \\
\text { location }\end{array}$ & Feedlot & Trailer & $\begin{array}{l}\text { Fecal } \\
\text { samples }\end{array}$ & \\
\hline AXO26A & O26 & $\mathrm{A}$ & $\mathrm{A}$ & $\mathrm{A}$ & $\mathrm{A}$ & May \\
\hline AYO26A & $\mathrm{O} 26$ & $\mathrm{C}$ & $\mathrm{C}$ & $\mathrm{C}$ & $\mathrm{C}$ & July \\
\hline AYO26B & $\mathrm{O} 26$ & $\mathrm{D}$ & $\mathrm{D}$ & $\mathrm{D}$ & $\mathrm{D}$ & August \\
\hline AXO103A & O103 & A & A & A & A & May \\
\hline AYO103A & O103 & $\mathrm{C}$ & $\mathrm{C}$ & $\mathrm{C}$ & $\mathrm{C}$ & July \\
\hline AYO111A & O111 & $\mathrm{C}$ & $\mathrm{C}$ & $\mathrm{C}$ & $\mathrm{C}$ & July \\
\hline AXO111A & O111 & $\mathrm{E}$ & $\mathrm{E}$ & $\mathrm{E}$ & $\mathrm{E}$ & July \\
\hline AXO121A & O121 & A & $\mathrm{A}$ & A & $\mathrm{A}$ & May \\
\hline AXO121B & O121 & B & B & B & B & May \\
\hline AYO145A & $\mathrm{O} 145$ & $\mathrm{C}$ & $\mathrm{C}$ & $\mathrm{C}$ & $\mathrm{C}$ & July \\
\hline AYO145B & $\mathrm{O} 145$ & D & $\mathrm{D}$ & $\mathrm{D}$ & $\mathrm{D}$ & August \\
\hline
\end{tabular}


Table 3 Taxonomy, genome size and morphology of 11 non-O157 STEC-infecting phages

\begin{tabular}{|c|c|c|c|c|c|c|}
\hline \multicolumn{2}{|c|}{ Taxonomy } & \multirow{2}{*}{ Phage isolates } & \multirow{2}{*}{$\begin{array}{l}\text { Estimated } \\
\text { genome } \\
\text { size }(\mathrm{kb})^{*}\end{array}$} & \multirow{2}{*}{$\begin{array}{l}\text { Head } \\
\text { dimensions } \\
(\mathrm{nm})\end{array}$} & \multicolumn{2}{|c|}{ Tail dimensions (nm) } \\
\hline Genus & Family & & & & Length & Width \\
\hline rV5 & Myoviridae & AXO121A & 140 & 93 & 122 & 17 \\
\hline $\mathrm{T} 4$ & Myoviridae & AYO26A, AXO121B & 177 & $115-117$ & $109-118$ & $21-24$ \\
\hline ViI & Myoviridae & AYO26B, AXO111A & 151 & $92-95$ & $100-102$ & $16-20$ \\
\hline \multirow[t]{2}{*}{ O1 } & Myoviridae & $\begin{array}{l}\text { AYO145A, } \\
\text { AYO145B }\end{array}$ & $68-89$ & $78-79$ & $113-114$ & $17-18$ \\
\hline & & AYO111A & 151 & 92 & 105 & 20 \\
\hline $\mathrm{T} 5$ & Siphoviridae & AXO26A, AXO103A & 126 & $82-85$ & $178-196$ & 10 \\
\hline $\mathrm{T} 7$ & Podoviridae & AYO103A & 38 & 57 & 8 & $\mathrm{ND}^{\dagger}$ \\
\hline
\end{tabular}

" Genome size was determined by pulsed field gel electrophoresis.

${ }^{\dagger} \mathrm{ND}$, not detected.

511 
Table 4 Sensitivity of 11 non-O157 STEC-infecting phages to 12 restriction enzyme

\begin{tabular}{|c|c|c|c|c|c|c|c|c|c|c|c|c|c|}
\hline \multirow{2}{*}{$\begin{array}{l}\text { Phage } \\
\text { isolates }\end{array}$} & \multicolumn{13}{|c|}{ Sensitivity to restriction enzymes } \\
\hline & Acc65 II & BamHI & EcoRI & EcoRV & HindIII & HaeII & KpnI & SacI & SalI & PstI & XbalI & XholI & Total $^{\dagger}$ \\
\hline $\mathrm{AXO} 26 \mathrm{~A}$ & + & + & + & + & + & + & + & & & + & + & & 9 \\
\hline $\mathrm{AYO} 26 \mathrm{~A}$ & & & & + & & & & & & & & & 1 \\
\hline AYO26B & & & + & + & & + & & & & & + & & 4 \\
\hline AXO103A & + & + & + & + & + & + & + & & & + & + & & 9 \\
\hline AYO103A & + & + & + & + & + & + & + & + & + & & & & 9 \\
\hline AXO111A & & & + & + & & + & & & & & + & & 4 \\
\hline AYO111A & & & + & + & & + & & & & & + & & 4 \\
\hline AXO121A & + & + & + & + & + & + & + & & & & + & & 8 \\
\hline AXO121B & & & & + & & & & & & & & & 1 \\
\hline AYO145A & & & & + & + & + & & & & & + & & 4 \\
\hline AYO145B & & & + & + & + & + & & & + & & & & 5 \\
\hline Total $^{+}$ & 4 & 4 & 8 & 11 & 6 & 9 & 4 & 1 & 2 & 2 & 7 & 0 & \\
\hline
\end{tabular}




\section{Figure captions}

$517 \quad$ Figure 1. Geographical location of fecal samples collected for isolation of non-O157

518 STEC-infecting phages. Each blue pentagram represents fecal sampling from either Mid Zone (B)

519 or South Zone (A, C-E) of Alberta, Canada.

Figure 2. Transmission electron microscopy of 11 non-O157-infecting phages. A, rV5-

522 like phages (AXO121A); B, T4-like phages (AYO26A and AXO121B); C, ViI-like phages

523 (AYO26B and AXO111A); D, O1-like phages (AYO145A and AYO145B); E, O1-like phage

524 (AYO111A); F, T5-like phages (AXO26A and AXO103A); G, T7-like phages (AYO103A); bar

525 represents $100 \mathrm{~nm}$; Preparations were negatively stained with uranyl acetate. Arrowheads point 526 to tail fibers where present.

Figure 3. Restriction fragment length polymorphisms of phage genomes alongside with

529 low range PFG markers. A, genomic DNA of AXO26A and AXO103A digested with HaeII,

530 HindIII and PstI, respectively B, genomic DNA of AXO121A, AYO26B, AYO111A and

531 AXO111A digested with HaeII; C, genomic DNA of AYO145A, AYO145B, AYO103A,

532 AXO121B and AYO26A digested with HaeII, SalI, EcoRI, EcoRV, and EcoRV, respectively. 


\section{Figure 1}

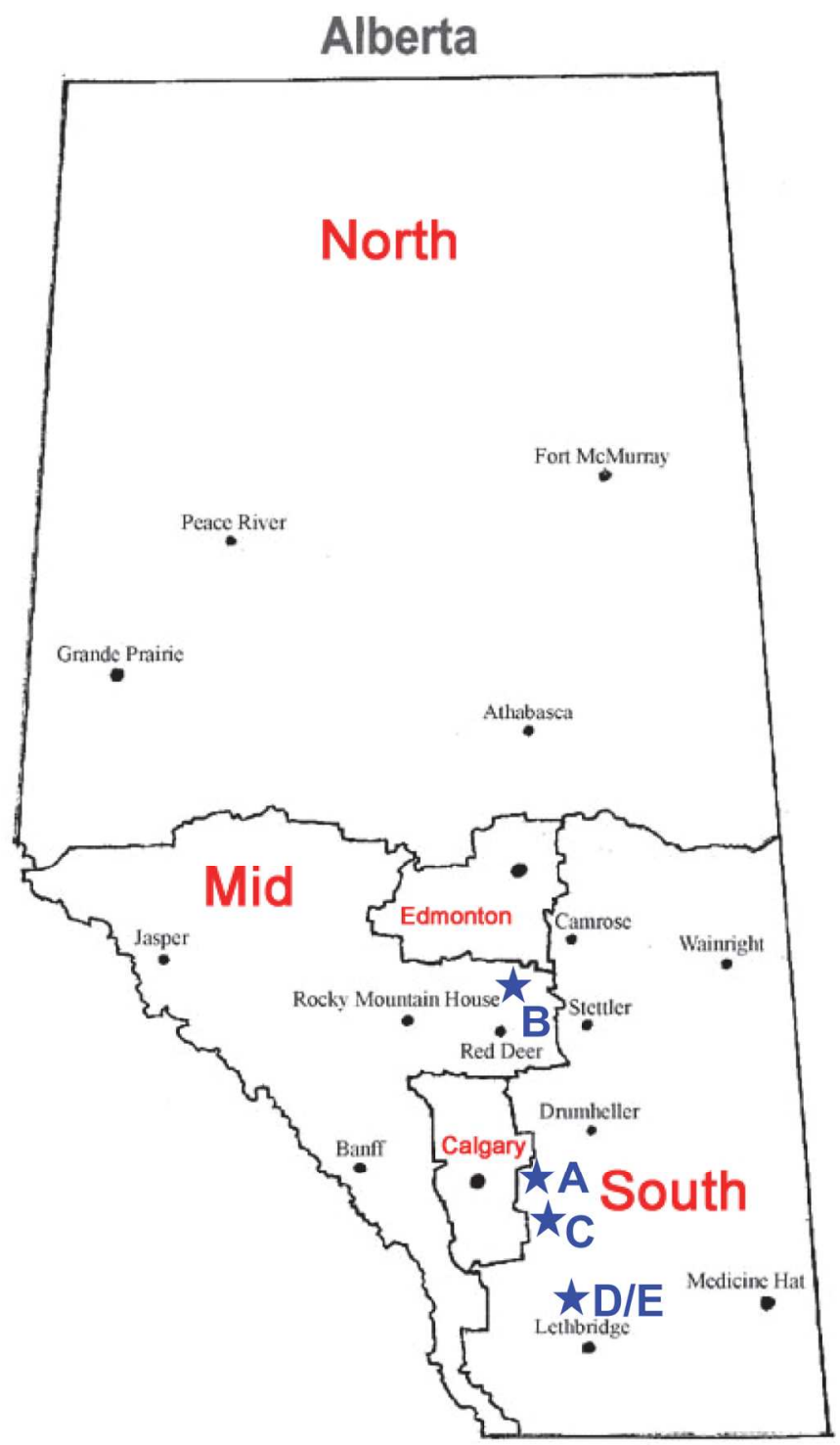

Figure 1. Geographical location of fecal samples collected for isolation of non-0157 STEC-infecting phages. Each blue pentagram represents fecal sampling from either Mid Zone (B) or South Zone ( $A, C-E)$ of Alberta, Canada. The map was adapted from Alberta Zone Map published by government of Canada (http://www.labour.gc.ca/eng/standards_equity/contracts/schedules/Alberta/map.shtml). $121 \times 172 \mathrm{~mm}(300 \times 300 \mathrm{DPI})$ 


\section{Figure 2}
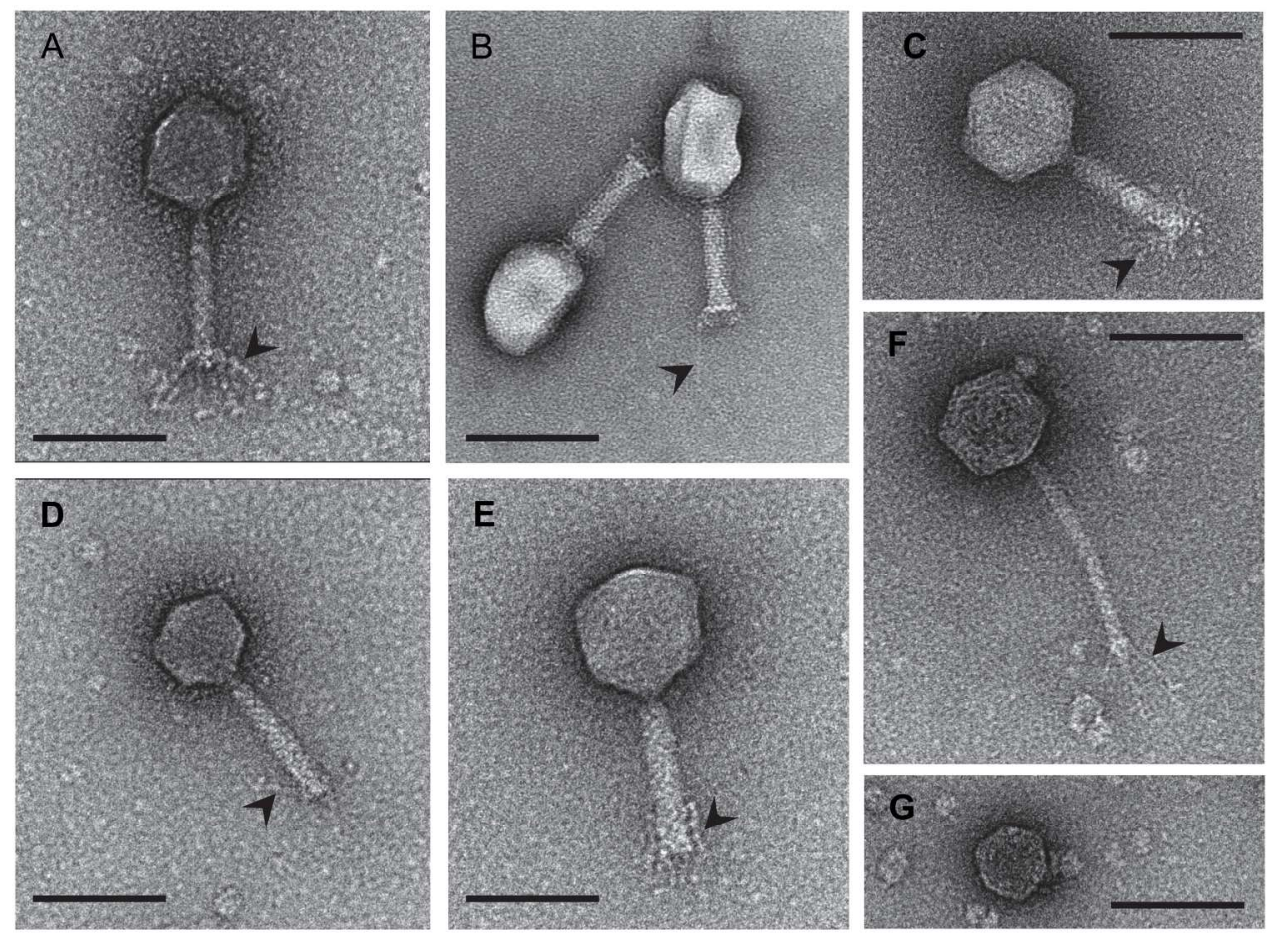

Figure 2. Transmission electron microscopy of 11 non-O157-infecting phages. A, rV5-like phages (AX0121A); B, T4-like phages (AYO26A and AXO121B); C, ViI-like phages (AYO26B and AXO111A); D, O1like phages (AYO145A and AYO145B); E, O1-like phage (AYO111A); F, T5-like phages (AXO26A and AXO103A); G, T7-like phages (AYO103A); bar represents $100 \mathrm{~nm}$; Preparations were negatively stained with uranyl acetate. Arrowheads point to tail fibers where present.

$210 \times 162 \mathrm{~mm}(300 \times 300 \mathrm{DPI})$ 
Figure 3

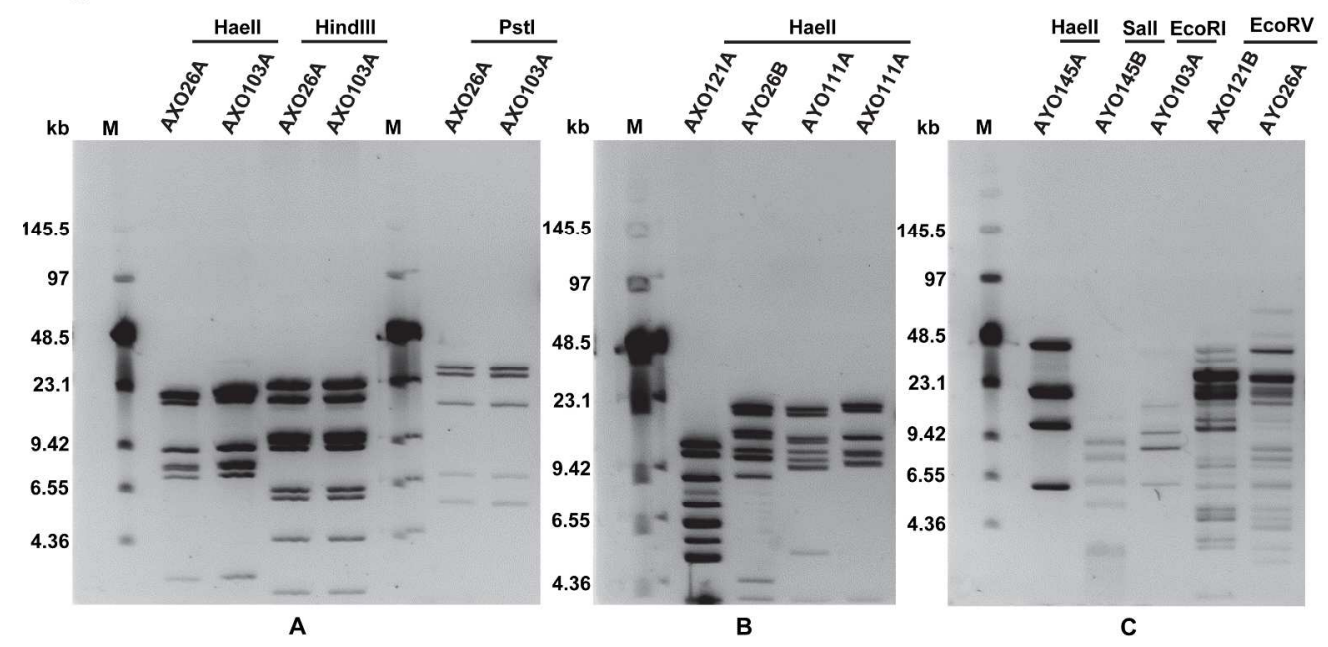

Figure 3. Restriction fragment length polymorphisms of phage genomes alongside with low range PFG markers. A, genomic DNA of AXO26A and AXO103A digested with HaeII, HindIII and PstI, respectively B, genomic DNA of AXO121A, AYO26B, AYO111A and AXO111A digested with HaeII; C, genomic DNA of AYO145A, AYO145B, AYO103A, AXO121B and AYO26A digested with HaeII, SalI, EcoRI, EcoRV, and EcoRV, respectively.

$230 \times 119 \mathrm{~mm}(300 \times 300 \mathrm{DPI})$ 